\title{
Antibacterial activity of phyto-mediated silver nanoparticles developed from Melia azedarach
}

\section{SUMERA JAVAD* \\ NADIA GHAFFAR \\ IQRA NASEER \\ KHAJISTA JABEEN \\ ARUSA AFTAB \\ SHABNAM SHAHEEN}

Dept. of Botany, Lahore College for Women University, Lahore, Pakistan

*Correspondence:

Sumera Javad

E-mail:Zif_4@yahoo.com

Key words: Green synthesis; Melia azedarach; UV Vis spectroscopy; antibacterial activity; Nanoparticles; silver nanoparticles
Received January 06, 2017.

Revised March 02, 2017.

Accepted March 12, 2017.

\section{Abstract}

Background: Nanoparticles formed by plant extracts present a good alternative of existing antibiotics to compete with the resistant strains of bacteria. Antioxidants present in plants synthesize the nanoparticles from metal salt and also cap them.

Methods: In the present study, Melia azedarach fresh leaves were extracted with water. These extracts were reduced by adding silver nitrate $\left(\mathrm{AgNO}_{3}\right)$ solution separately. Plant extract in different volumes was used to develop nanoparticles with constant strength of salt solution. Color change of extracts represented the development of silver nanoparticles due to reduction of silver ions to form silver nanoparticles. Absorbance of reaction mixtures were determined by UVVis spectrophotometry. Further antimicrobial activity of these nanoparticles was tested against Borditella pertussis and Xanthomonas axonopodis by agar well diffusion method.

Results: Maximum absorbance was noticed between 400-500 nm. EDX analysis proved the presence of silver ions and SEM analysis showed size and shape of nanoparticles $(105 \mathrm{~nm})$. Silver nanoparticles developed from water extract of $\mathrm{M}$. azedarach exhibited maximum inhibition zones $(25.4 \pm 0.36 \mathrm{~mm})$ and $(47.2 \pm 0.25 \mathrm{~mm})$ against Borditella pertussis and Xanthomonas axonopodis respectively.

Conclusions: The conclusion was established that silver nanoparticles from $\mathrm{M}$. azedarach revealed enhanced antibacterial activity with comparison to pure plant extract and silver nitrate solution and can be used in different antibacterial products.

\section{INTRODUCTION}

roups of atoms size ranging from $1-100 \mathrm{~nm}$ are nanoparticles. TThese nanoparticles have many chemical, optical and mechanical properties. Nano technology has been used widely in physical, chemical and biological processes. Nanotechnology has evolved as a growing new field and has many applications especially in the biosciences and technology by forming new products at nanoscale level. Biosynthetic methods are being used nowadays by using both biological organisms such as plant extracts, fungus and bacteria.These methods have emerged as a simple and viable alternative as compared to more difficult chemical methods for nanoparticles. Different nanoparticles like copper, zinc, titanium, magnesium, gold and silver are being used but silver nanoparticles have proved to be most effective as it has good antimicrobial efficacy against bacteria, viruses and other eukaryotic microorganisms $(1-3)$. 
Many previous studies showed that several plants have been used for synthesis of silver nanoparticles such as $E u$ phorbia prostrate, Mollugo nudicaulis, Calatropis gigantea, Epipremnum aureum, Padina tetrastromatica, Cissus quadrangularis, Spinacia oleracea and Lactuca sativa (4).

Biosynthesized nanoparticles by plants can be used in different fields like cosmetics, medicines and food industry. Silver is well known for its antimicrobial effect in medicine and industrial products (5). Silver nanoparticles can be used for the prevention of AIDS because they interact with the HIV-1 virus (6). These are often used in ointments for curing infections against burn and open wounds. As silver nanoparticles have antimicrobial activity, so these are employed in textile, food, packaging and plastic industry. These nanoparticles are also being used in room sprays, laundry detergents, and wall paints (7-8).

Melia azedarach is known by many names such as white cedar, chinaberry tree, bead-tree, Cape lilac, syringa berry tree, and Persian lilac. In Punjab parts of Pakistan it is locally known as Dharek. It belongs to family Maliaceae. The height of adult tree is 7-12 meters or 20-40 ft.The leaves of Melia plant are 50 centimeters or 20 inches in length, show alternate phyllotaxy with dark green upper surface and lighter green lower surface. They are odd pinnate with serrate margins. Flowers are small and grow in clusters. They are usually purple in color and small size. They also give specific fragrance. Its fruit is drupe, green in color but yellow when mature. It is small size and grow in clusters which remain hanging in winter and at the end of season become wrinkled and white.

Melia leaves contain a compound named Meliacine which has effectiveness against Herpes Simplex type 1 virus. The leaves and fruits of these plants contain antimicrobial properties. Meliaceae family is rich in terpenoids of limonoid types. Some of the chemical compounds such as sulfur, hydrocarbon, fatty acid, di-terpenoids, sterols, phenol, flavonoid, glycosides, lactones, azadirachtin, nimbin, nimboslin, quercetin, escopolnenin, azadiyeron, azadiyeradion, -14 opeksi, azadyeridon, gedonin, nimosinulnimosinolid, nimbandion, salanol, nimbinen, - 6 dastilnimbinen, margozonolid, isomargozonolid, meyanetriol, salanin (its 14 derivatives), feraksinoloz, sinamat, meliasin, A and B nimbolins and limonoid are important biochemical of this family. In higher plants, apart from enzymes, other molecules such as polyols, heterocyclic compounds and flavonoids may have a role in the synthesis of nanoparticles. Terpenoids can reduce silver ions to silver while getting transformed to the corresponding carboxylic acids (9-10). As we know that bacteria are becoming resistant to antibiotics gradually, so research is going on worldwide to get nanoparticles naturally and use them as antibiotic agents as well as for drug delivery.

In present study, potential of Melia plant to form nanoparticles to evaluate its use as a raw material for green synthesis of nanoparticles was studied.

\section{MATERIALS AND METHODS}

Current experimental work was done in Biochemistry lab of Botany department in Lahore College for Women University, Lahore Pakistan.

\section{Preparation of plant extract}

The fresh leaves of $M$. azedarach were collected from premises of LCWU. For making extract, $30 \mathrm{~g}$ of fresh leaves were weighed on electric balance and crushed in pestle and mortar. Crushed material was placed in beaker with $200 \mathrm{~mL}$ of water each time. Sample was then heated in microwave for 60 seconds to form plant extract and it was filtered by using whatmann No 1 filter paper. Fine extract was obtained to develop Nano particles.

\section{Preparation of reagent}

Silver nitrate $\left(\mathrm{AgNO}_{3}\right) 0.68 \mathrm{~g}$ was dissolved in $100 \mathrm{ml}$ of water to make the stock solution of $\mathrm{AgNO}_{3}$ and $10 \mathrm{ml}$ of this solution was added in each concentration of plant extract.

\section{Development of nanoparticles}

Different volumes $(5,10,20,25,30 \mathrm{ml})$ of plant extract with water separately were added in beaker along with $10 \mathrm{ml}$ of silver nitrate $\left(\mathrm{AgNO}_{3}\right)$ and left for 2 hours. Over that period of time, change in colors was observed and pictures were taken. After 2 hours $1 \mathrm{ml}$ of each concentration was taken in Eppendorf to centrifuge. These samples were centrifuged at $5000 \mathrm{rpm}$ for 15 minutes. Small pellets of nano particles developed which were washed thrice with distilled water and preserved to be used for further analysis.

\section{Characterization of nanoparticles}

Synthesized AgNPs were characterized by using techniques of UV-visible spectroscopy, scanning electron microscope (SEM) and Energy dispersive X-ray spectroscopy. Size of all particles was also analysed by Particle size analyzer from Nanochemistry Department, GC Universty Lahore Pakistan.

\section{Antibacterial activity}

Synthesized silver nanoparticles from different Melia extracts were tested to determine their antibacterial activity against two pathogenic bacteria species Borditella pertussis and Xanthomonas axonopodis. Antimicrobial assay included agar well diffusion method in which $2 \%$ nutrient agar media was prepared and $20 \mathrm{ml}$ of it was poured in each petri plate and boring was done by standard borer. After that, bacterial strains were inoculated then in these petri dishes. For this purpose $20 \mathrm{mg}$ of each pallet was dissolved in $10 \mathrm{ml}$ of water. Then 1 drop of different reacting volumes of the extract was tested each 
against these strains. After incubation of 24 hours, zones of inhibition were seen which confirmed the antimicrobial activity of nanoparticles with both bacterial strains. Moreover these inhibitory zones were measured to check the nanoparticle antimicrobial activity with plant extract.

\section{Statistics}

Data was collected in 3 replicates. Standard Deviation was calculated. Thus generated data was then examined by one way analysis of variance (ANOVA) with the help of COSTAT computer software.

\section{RESULTS}

\section{Nanoparticle biosynthesis}

For this purpose different volume of Melia leaves extract i.e. 5, 10, 15, 20, 25, $30 \mathrm{ml}$ were taken separately and $10 \mathrm{ml}$ of $4 \mathrm{mM}$ silver nitrate $\left(\mathrm{AgNO}_{3}\right)$ solution was added in each volume. Then it was allowed to react, the colors of all solutions were light greenish which turned into brownish after 2 hours and it indicated the formation of nanoparticles (Fig1-2). There was clear change in color in different volumes.

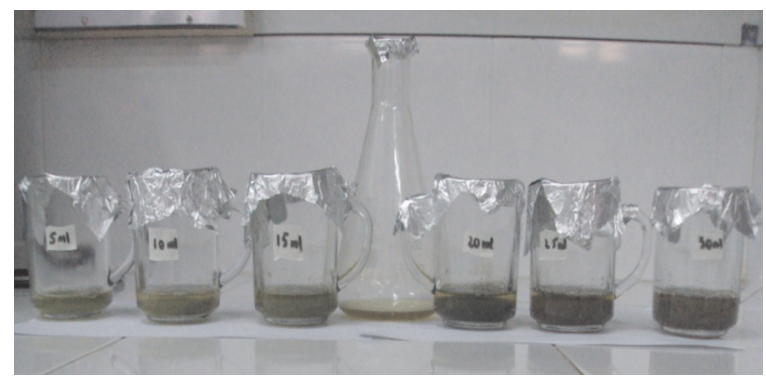

Figure 1. Color of plant water extract with $\mathrm{AgNO}_{3}$, start of experiment.

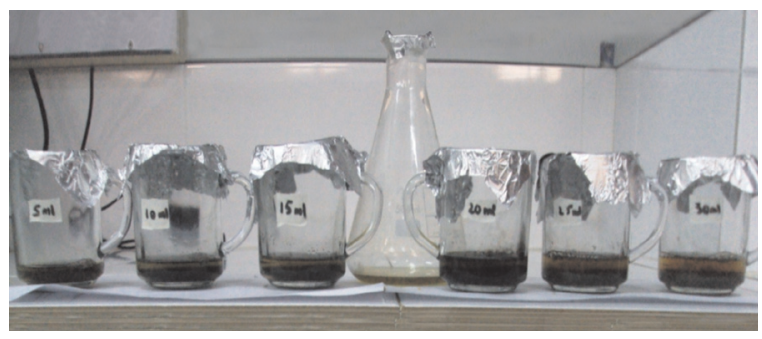

Figure 2. Color of plant water extract with $\mathrm{AgNO}_{3}$, after 2 hours.

\section{UV-Vis spectrophotometer}

UV Vis spectrophotometry was done to characterize and determine the silver nanoparticles in the Melia azedarach fresh leaves solution with silver nitrate $\left(\mathrm{AgNO}_{3}\right)$. Extracts of Melia leaves with acetone, ethanol, methanol and water were used. It was observed that $U V \lambda_{\max }$ ranged between $400 \mathrm{~nm}$ to $500 \mathrm{~nm}$ in all reacting solvents (Fig 3).

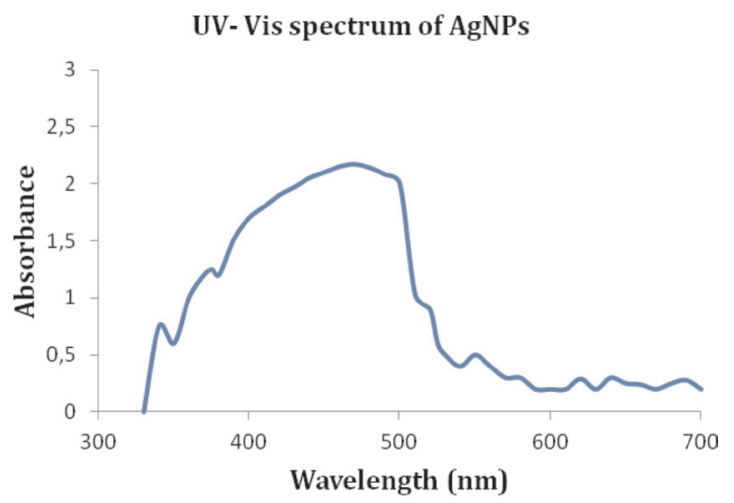

Figure 3. $U V$-Vis spectrum of $A g N P$ s

\section{Energy dispersive X-ray analysis}

It confirmed the presence of silver in all reacting solutions. Pure silver was present in the centrifuged material and it was confirmed by EDX. This technique is also used to check the composition as well ascrystalline nature of nanoparticles. Peaks around $3 \mathrm{keV}$ seen in EDX pattern which confirmed the formation of nanoparticles (Fig 4).

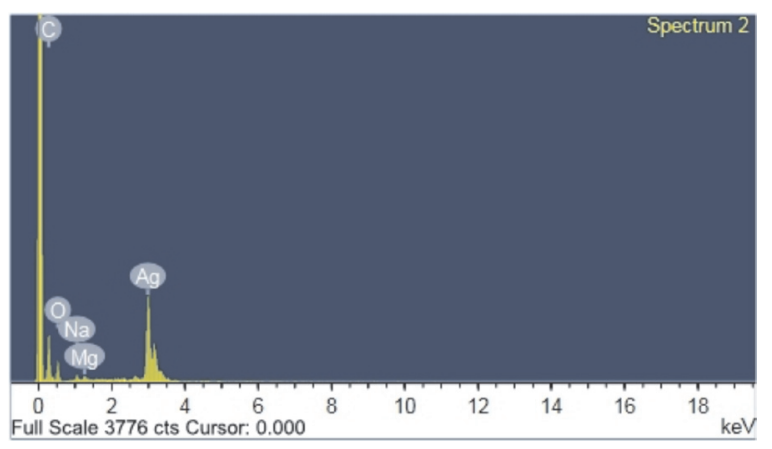

Figure 4. EDX pattern of Silver nanoparticles

\section{Scanning electron microscope analysis}

Surface morphology of silver nanoparticles was demonstrated by scanning electron microscopy. It showed different particle shapes and sizes in different solvents. The size of the particles was from Nano to micron range and morphology of particles was nearly spherical with minimum size of $105 \mathrm{~nm}$. The size of the prepared nanoparticles was more than the size of nanoparticlesi.e.; between 1-100 $\mathrm{nm}$. This was because the proteins were bound to the surface of the nanoparticles. As the ratio differs size also differs, this is because of the concentration variations (Fig 5). 


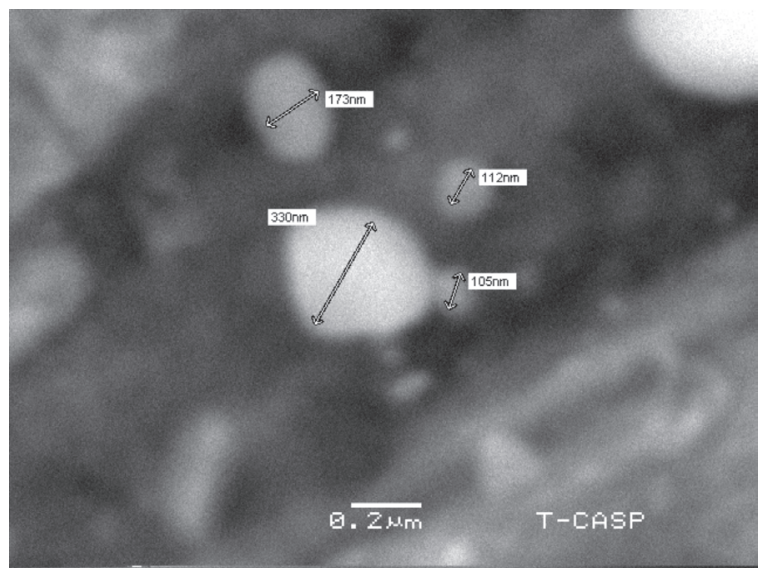

Figure 5. SEM micrograph

\section{Agar Well diffusion method}

Moreover, synthesized nanoparticles were tested for antibacterial activity (Table 1). It was done by agar well diffusion method against Borditella pertussis and Xanthomonas axonopodis. Maximum inhibition zones were observed in water extract of Melia against Xanthomonas axonopodis. Statistical analysis also showed the value of inhibition zones $(47.2 \pm 0.25 \mathrm{~mm})$ and $(25.4 \pm 0.36 \mathrm{~mm})$ with AgNPs of Melia leaves and $(12.18 \pm 0.22 \mathrm{~mm})$ and $(21.3 \pm 0.11 \mathrm{~mm})$ with pure plant extract against $X$. axonopodis and B. pertussis respectively (Fig 6-7).

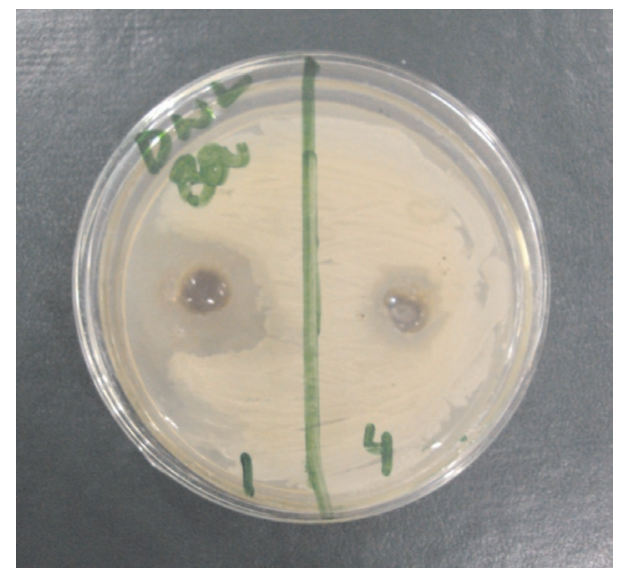

Figure 6. Antibacterial activity of aqueous AgNPs by Melia leaves extract against Xanthomonas axonopodis (1 is for AgNPs and 4 is for standard plant extract).

Statistical analysis showed that AgNPs produced a larger inhibition zone of $(47.2 \pm 0.25 \mathrm{~mm})$ as compared to plant extract i.e. $(12.18 \pm 0.22 \mathrm{~mm})$ against Xanthomonas axonopodis (Fig 6). Similarly increased antibacterial activity of AgNPs was noticed against Borditella pertussis $(25.4 \pm 0.36 \mathrm{~mm})$ as compared to that of plant extracts i.e. $(21.3 \pm 0.11 \mathrm{~mm})$ (Fig 7).

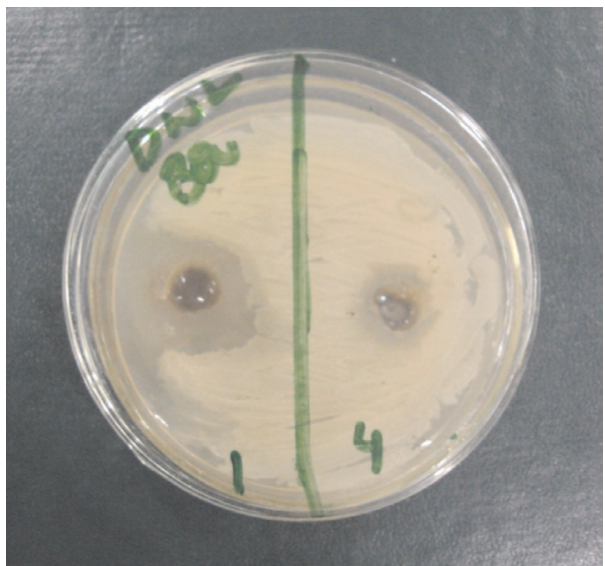

Figure 7. Antibacterial activity of aqueous AgNPs by Melia leaves extract against Borditella pertussis ( 1 is for AgNPs and 5 is for standard plant extract).

Table 1. Antibacterial activity of AgNPs prepared from different volumes of plant extract

\begin{tabular}{|cccc|}
\hline \multirow{2}{*}{$\begin{array}{c}\text { AgNPs } \\
\text { prepared from } \\
\text { different } \\
\text { volume of } \\
\text { plant extract }\end{array}$} & $\begin{array}{c}\text { Particle } \\
\text { Size }\end{array}$ & \multicolumn{2}{c|}{$\begin{array}{c}\text { Inhibition zones against } \\
\text { Bacterial Strains }\end{array}$} \\
\cline { 3 - 4 } Control & --- & $\begin{array}{c}\text { Xanthomonas } \\
\text { axonopodis }\end{array}$ & $\begin{array}{c}\text { Borditella } \\
\text { pertussis }\end{array}$ \\
\hline $\mathrm{mL}$ & $105 \mathrm{~nm}$ & $47.8^{\mathrm{e}} \pm 0.22$ & $21.3^{\mathrm{b}} \pm 0.11$ \\
$10 \mathrm{~mL}$ & $208 \mathrm{~nm}$ & $27.9^{\mathrm{b}} \pm 0.15$ & $25.4^{\mathrm{a}} \pm 0.36$ \\
$15 \mathrm{~mL}$ & $213 \mathrm{~nm}$ & $21.4^{\mathrm{c}} \pm 0.36$ & $17.3^{\mathrm{c}} \pm 0.32$ \\
$20 \mathrm{~mL}$ & $201 \mathrm{~nm}$ & $18.4^{\mathrm{d}} \pm 0.26$ \\
$25 \mathrm{~mL}$ & $220 \mathrm{~nm}$ & $12.0^{\mathrm{e}} \pm 0.20$ & $16.4^{\mathrm{c}} \pm 0.36$ \\
$30 \mathrm{~mL}$ & $261 \mathrm{~nm}$ & $15.0^{\mathrm{de}} \pm 0.3$ & $13.4^{\mathrm{cd}} \pm 0.36$ \\
\hline
\end{tabular}

\section{DISCUSSION}

Metals like gold and silver are known to form nanoparticles when they interact with plant extracts. Plant extracts have a number of antioxidants which help to reduce metals into their nanoparticles. Formation of nanoparticles is studied by a variety of characterization tests from which a few are selected for present study. Nanoparticles have surface Plasmon resonance which is their absorption capacity and it is specific to the particular metal (9). Color change is also due to excitation in surface Plasmon resonance which is the sign of silver nanoparticles formation (4). So color change of the reaction mixture and peculiar peaks of the UV-vis spectrum give initial indication of the nanoparticles formation. Results can be correlated with the previous work in which colloidal silver solution had leaf extract of Melia azedarach which showed peak at 482 $\mathrm{nm}$ after 6 hours of reaction. This was a technique for the confirmation of AgNPs in the solution. Previous studies 
revealed that in UV region, AgNPs gave a distinctive absorbance band because of surface plasmon excitation mode which depends upon silver nanoparticle size (10).

Earlier studies show that metallic silver shows peaks near about $3 \mathrm{eV}$ in the EDX analysis which is a direct proof of the silver nanoparticles formation. SEM images confirm the morphology of nanoparticles formed. These are used as authenticated sources to confirm the nanoparticles formation by different metal salts and plant extracts (11-13).

Bacterial growth of two strains namely Borditella pertussis and Xanthomonas axonopodis, was also stopped because of silver nanoparticles. This is in accordance with the literature. First strain is a plant parasite while second one is a human pathogen causing respiratory disorder. Efficient antibacterial compounds will definitely add to the health benefits for human directly and indirectly (14-15).

There are different studies which show that silver nanoparticles gather into the vacuole and cell walls as granules. AgNPs stop cell division and destroy the cell envelope and contents of the bacteria. Further, silver ions can damage the nucleic acids. In this way silver nanoparticles show strong bactericidal effect which can be exploited for human cause on commercial level (16-18).

\section{CONCLUSIONS}

UV Vis spectrophotometry, EDX analysis and SEM analysis confirmed the presence of silver nanoparticles in M. azedarach leaves extract treated with $\mathrm{AgNO}_{3}$. Antibacterial activity showed efficacy of AgNPs against pathogenic bacterial strains. These nanoparticles can be used in various fields e.g. medical, cosmetics and packaging industry.

Acknowledgement: We Acknowledge Centre for Advance Studies in Physics, Govt. College University, Lahore Pakistan for their assistance in SEM analysis.

\section{REFERENCES}

1. ALBRECHT MA, EVANS CW, RASTON CL 2006 Green chemistry and the health implications of nanoparticles. Green Chem 8: 417-432. https://doi.org/10.1039/b517131h

2. SHANKAR SS, AHMAD A, PASRICHA R, SASTRY M 2003 Bioreduction of chloroaurate ions by Geranium leaves and its endophytic fungus yields gold nanoparticles of different shapes. J of Mat Chem 13: 1822-1826. https://doi.org/10.1039/b303808b

3. GONG PLH, WANG KHJ, TAN W 2007 Preparation and antibacterial activity of $\mathrm{Fe}_{3} \mathrm{O}_{4}$ against $\mathrm{Ag}$ nanoparticles. Nanotech 18: 604-611. https://doi.org/10.1088/0957-4484/18/28/285604
4. MEHMOOD A, MURTAZA G, BHATTI TM, KAUSAR R 2013 Phyto-mediated synthesis of silver nanoparticles from Melia azedarach L. leaf extract: Characterization and antibacterial activity. Arab J of Chem 14: 212-215.

5. REDA M, SHESHTWY EI, ABDULLAH M NA,YERA A 2011 In situ production of silver nanoparticles on cotton fabric and its antimicrobial evaluation. Cellulose 18: 75-82

6. ELECHIGUERRA JL, BURT JL, MORONES JR, CAMACHOBRAGADO A, GAO X LARA HH, YACAMAN MJ 2005 Interaction of silver nanoparticles with HIV-1. Journal of Nano biotech 3: $16-19$

7. LOKET CN, HO CM, CHEN R, HE QY, YU WY, SUN H 2007 Silver nanoparticles: partial oxidation and antibacterial activities. J of Biol Inorg Chem 12: 527-534. https://doi.org/10.1007/s00775-007-0208-z

8. SUN Y, XIA Y 2002 Shape-controlled synthesis of gold and silver nanoparticles. Science 298: 2176-2179. https://doi.org/10.1126/science.1077229

9. MEHMOOD A, MURTAZA G, BHATTI TM, RAFFI M, KAUSAR R 2014 Antibacterial Efficacy of Silver Nanoparticles Synthesized by a Green Method Using Bark Extract of Melia azedarach L. J of Pharm Innov 9: 238-245. https://doi.org/10.1007/s12247-014-9190-5

10. KATHIRAVAN V RAVI S ASHOKKUMAR S 2014 Synthesis of silver nanoparticles from Melia dubia leaf extract and their in vitro anticancer activity. Biomolecular spectroscopy 130: 116-121

11. JYOTI K MAMTA B AJEET S 2016 Characterization of silver nanoparticles synthesized using Utrica dioica Linn. Leaves and their synergistic effects with antibiotics. J of Rad and Appl Sci 9: 217-227

12. PUCHALSKI M, DABROWSKI P, OLEJNICZAK W, KRUKOWSKI P, KOWALCZYK P, POLANSKI K 2007 Material Science-Poland 25: 473-478

13. DIMITRIJEVIC R, CVETKOVIC O, MIODRAGOVIC Z SIMIC M, MANOJLOVIC D, JOVIC V 2013 SEM/EDX and XRD characterization of silver nanocrystalline thin film prepared from organometallic solution precursor. J Min Metall Sect BMetall 49: 91-95. https://doi.org/10.2298/JMMB120111041D

14. GILBERG S, ELISABETH N, ISABELLE P C, HENRI P, PASCALE G, CHRISTIAN G, MARTIN S, NICOLE G 2002 Evidence of Bordetella pertussis Infection in adults presenting with persistent cough in French area with very high whole cell vaccine coverage. The $\mathrm{j}$ of infectious diseases 186: 415-418

15. DOW J, M LISA C, KIM F, YONG Q H, JIA X F, JI L T 2003 Biofilm dispersal in Xanthomonas campestris is controlled by cellcell signaling and is required for full virulence to plants. Proceedings of national academy of sciences of United States of America 100: 10995-11000

16. BROWN T, SMITH D 1976 The effects of silver nitrate on the growth and ultrastructure of the yeast Cryptococcus albidus. Micro Biosci Lett 3: 155-162

17. SHAMS S, POURSEYEDI S, RAFSANJANI HH 2014 Green Synthesis of Silver Nanoparticles and Its Effect on Total Proteins in Melia azedarach Plant. Int J of Nanosci 10: 181-186

18. YAKABE Y, SANO T, USHIO H, YASUNAGA T 1980 Kinetic studies of the interaction between silver ion and deoxyribonucleic acid. Chem Lett 4: 373-376. https://doi.org/10.1246/cl.1980.373 